\title{
The impact of vitamin $D$ deficiency and autoimmunity on chronic spontaneous urticaria severity
}

\author{
Vitamin D eksikliğinin ve otoimmünitenin kronik spontan ürtiker
} șiddetine etkisi

๑ Nurcan Metin, $\odot$ Mustafa Teoman Erdem*

University of Health Sciences Turkey, Erzurum Regional Training and Research Hospital, Clinic of Dermatology, Erzurum, Turkey *Private Adatıp Sakarya Hospital, Clinic of Dermatology, Sakarya, Turkey

\begin{abstract}
Background and Design: In this study, we investigated the role of vitamin D deficiency and autoimmunity in chronic spontaneous urticaria (CSU) etiopathogenesis and their impact on the disease severity.

Materials and Methods: Sixty patients with CSU aged between 18 and 65 years were enrolled to the study. The control group comprised 40 healthy individuals who had no episodes of urticaria or any other chronic diseases. An autologous serum skin test (ASST) was performed in all patients. In addition, 25 hydroxyvitamin D, thyroid autoantibodies (TA), anti-nuclear antibody (ANA), and basophils were evaluated in all groups. Urticaria activity score-7 (UAS7) and dermatological quality of life index (DLQI) of all patients were examined.

Results: Angioedema was more frequent and UAS7 was higher in ASST-positive patients than ASST-negative patients $(p=0.035, p=0.018$, respectively). $<10 \mathrm{ng} / \mathrm{mL}$ vitamin $D$ levels were more fraquently seen in the patients with $C U$ than in the control group ( $p=0.002)$. The frequencies of TA and ANA positivity were higher, and basophil count was lower in all patients compared to the control group ( $p=0.001$, $p=0.001, p=0.001$, respectively). The quality of life was more impaired in patients with positive ASST $(p=0.011)$. The duration of the disease was longer, and UAS7 was higher in patients with positive-TA ( $p=0.012, p=0.028$, respectively). UAS7 was significantly higher in ANA-positive patients $(p=0.042)$. A significant negative correlation was found between the DLQI and basophil counts $(p=0.039)$.

Conclusion: Understanding the role of vitamin D deficiency, autoimmunity in CSU etiopathogenesis may help treat severe diseases.
\end{abstract} Keywords: Urticaria, vitamin D, thyroid antibodies, anti-nuclear antibody, basophils

Öz

Amaç: Bu çalışmada kronik spontan ürtiker (KSÜ) etiyopatogenezinde D vitamini eksikliği ve otoimmünitenin rolünü ve bunların hastalık şiddetine etkisini araştırmayı amaçladık.

Gereç ve Yöntem: On sekiz-altmış beş yaşları arasındaki 60 KSÜ hastası çalışmaya dahil edildi. Kontrol grubu daha önce ürtiker atağı geçirmemiş ve kronik hastalığı olmayan 40 sağlıklı bireyden oluşuyordu. Tüm hastalara otolog serum deri testi (ASST) yapıldı. Tüm gruplarda 25 hidroksivitamin D, tiroid otoantikorları (TA), antinükleer antikor (ANA) ve bazofiller değerlendirildi. Tüm hastaların ürtiker aktivite skoru-7 (UAS7) ve dermatolojik yaşam kalitesi indeksi (DLQI) incelendi.

Bulgular: ASST pozitif olan hastalarda anjiyoödem, ASST negatif olanlara göre daha sık ve UAS7 daha yüksekti (sırasılla; $p=0,035, p=0,018)$. $<10 \mathrm{ng} / \mathrm{mL}$ D vitamini düzeyleri hastalarda sağlıklı kontrollere göre daha sıktı $(p=0,002)$. Tüm hastalarda kontrol grubuna göre TA ve ANA daha yüksekti ve bazofil sayısı daha düşüktü (sırasılla; $p=0,001, p=0,001, p=0,001$ ). ASST-pozitif hastalarda yaşam kalitesi daha fazla bozulmuştu $(p=0,011)$. TA-pozitif olan hastalarda hastalık süresi daha uzundu ve UAS7 daha yüksekti (sırasılya; $p=0,012, p=0,028)$. ANA-pozitif olan hastalarda UAS7 anlamlı olarak daha yüksekti $(p=0,042)$. DLQI ve bazofil sayııı arasında anlamlı negatif korelasyon bulundu $(p=0,039)$.

Sonuç: KSÜ etiyopatogenezinde D vitamini eksikliğinin ve otoimmünitenin rolünü anlamak, şiddetli hastalığı tedavi etmemize yardımcı olmaktadır.

Anahtar Kelimeler: Ürtiker, D vitamini, tiroid antikorları, anti-nükleer antikor, bazofiller

Address for Correspondence/Yazışma Adresi: Nurcan Metin MD, University of Health Sciences Turkey, Erzurum Regional Training and Research Hospital, Clinic of Dermatology and Venereology, Erzurum, Turkey Phone: +90 $5075806255 \mathrm{E}$-mail: drnurcanmetin@hotmail.com Received/Geliş Tarihi: 16.05.2020 Accepted/Kabul Tarihi: 14.10.2020 ORCID: orcid.org/0000-0002-1251-6333

Cite this article as: Metin N, Erdem MT. The impact of vitamin D deficiency and autoimmunity on chronic spontaneous urticaria severity. Turkderm-Turk Arch Dermatol Venereol 2021;55:70-4.

(c) Copyright 2021 by Turkish Society of Dermatology and Venereology

Turkderm - Turkish Archives of Dermatology and Venereology published by Galenos Yayinevi. 


\section{Introduction}

Urticaria is a cutaneous vascular reaction involving the dermis, formed by itchy, erythematous, edematous papules, and plaques. Chronic urticaria (CU) lesions persist for six weeks or longer. Many factors were attributed to the etiology of urticaria, such as drugs, infections, inhalants, foods, insect stings, internal diseases, and malignancies. However, no such triggering factors are found in $80 \%$ of patients with $\mathrm{CU}$. There are strong indications from several studies that functional histamine-releasing antibodies against $\alpha$ subunit of high-affinity immunoglobulin $\mathrm{E}$ ( $\mathrm{IgE}$ ) receptors (FcERI- $\alpha$ ) and/or IgE are present in $45 \%$ of patients with chronic spontaneous urticaria (CSU). Autologous serum skin test (ASST) is a cheap and easy in vivo test used to determine the functional antibodies, and the test-specificity and sensitivity are approximately $80 \% \%^{1-3}$.

Today, many data show that vitamin D affects the immune system, and its low level is associated with autoimmune diseases. Further, the studies also have shown that thyroid autoantibodies (TA) such as antithyroglobulin (anti-Tg) and anti-thyroid peroxidase (anti-TPO) and some other autoimmune markers such as anti-nuclear antibodies (ANA) are present at high levels in patients with autoimmune diseases. It has been attributed that the disease is more resistant to treatment and has a severe and prolonged course in patients who tested positive for such autoimmune markers ${ }^{4,5}$. Another marker, basopenia, is found more frequently in patients with CSU. However, the exact role of basophils in this disease has not been established. It has been long known that peripheral blood basophils from CSU patients have important properties that impede the response to therapy. This was first reported as early as 1962 by Rorsman and confirmed later by Grattan and Eckman, who found a correlation between basophils and the severity of urticaria. Interestingly, Rorsman found that the presence of a reduced number of basophils is associated with the presence of an antigen-antibody reaction. This leads to degranulation of basophils resulting in autoimmune disease $e^{6,7}$.

\section{Materials and Methods}

Sixty out of 80 patients with CSU, aged 18-65 years who applied to Sakarya University Training and Research Hospital, Clinic of Dermatology between 1 January-31 March, 2015 were included in the study. All patients were questioned about suspicious food, drugs, infection, triggering physical agents, psychological stress, and internal diseases that may instigate urticaria. Complete blood count, glucose level, liver function tests, renal function tests, electrolytes, urinalysis, erythrocyte sedimentation rate, C-reactive protein, hepatitis B surface antigen, hepatitis $C$ antibodies, total $\lg E$, and thyroid function tests were performed to evaluate the patients. The patients with abnormal laboratory findings that may trigger urticaria were excluded from the study. The patients with acute urticaria, who received vitamin D supplements in the last 3 months, systemic drug users, and pregnant women were excluded. Fourty healthy individuals without a history of urticaria, systemic diseases, and drug use were included as the control group considering a homogeneous distribution of sex and age. Because of the seasonal variability of vitamin $D$, the patients and the controls were evaluated within the 3 months, including winter-spring months. ASST was performed, and the dermatology life quality index (DLQI) and urticaria activity score-7 (UAS7) were examined in the patients. 25 hydroxyvitamin D [25(OH)D], anti-TG, anti-TPO, and ANA levels were evaluated in the patient and control group. The study was approved by the Ethics Committee of Sakarya University Clinical Research Ethics Committee, Turkey (approval number: 16214662) and was conducted as per the latest version of the "Helsinki Declaration" and under the "Guidelines for Good Clinical Practice."

\section{Statistical Analysis}

All statistical analyses were performed using SPSS version 18 . To verify the normal distribution of the variables, Kolmogorov-Smirnov/Shapiro-Wilk tests were performed. Student's t-test, Mann-Whitney U test, chi-square test, Pearson and Spearman correlation analysis, along with post-hoc analysis, were used to determine the differences between the groups.

\section{Results}

Out of 60 patients, 41 were female (68.3\%), 19 were male (31.6\%), and they are aged between 18 and 65 years. Twenty-six of 40 individuals in the control group were female (65\%), and 14 were male (35\%). The age of the control group was comparable to that of the patient group. ASST was positive in 50\% (30 patients) and negative in 50\% (30 patients) of patients. Disease duration was between 2 and 300 months in ASST-positive patients and between 2 and 180 months in ASST-negative patients. The angioedema was found in 22 ASST-positive patients and 14 ASST-negative patients. The average [standard deviation (SD)] UAS7 was $5.43 \pm 0.67$ in the ASST-positive group and $4.67 \pm 1.29$ in the ASST-negative group. The average (SD) of DLQI was $14.47 \pm 6.47$ in ASST-positive patients and 10.20 \pm 6.07 in ASST-negative patients (Table 1). There was no significant difference in terms of sex and disease between the patients with positive ASST and negative ASST. It was determined that angioedema was accompanied more frequently, and UAS7 was significantly higher in ASST-positive than ASST-negative patients ( $p=0.035$ and $p=0.018$, respectively). The quality of life was more impaired in ASST-positive patients $(p=0.011)$. $25(\mathrm{OH}) \mathrm{D}$ levels $<30 \mathrm{ng} / \mathrm{mL}$ were observed in 58 individuals from the patient group and 33 individuals from the control group. According to $25(\mathrm{OH}) \mathrm{D}$ levels, the patients and controls were further divided into two groups: Severe deficiency $(<10 \mathrm{ng} / \mathrm{mL})$ and the deficiency $(10-29$ $\mathrm{ng} / \mathrm{mL}$ ). In the patient group, 19 individuals (32.7\%) showed severe deficiency, and 39 individuals (67.24\%) showed a deficiency of $25(\mathrm{OH})$ $\mathrm{D}$ levels. In the control group, 25(OH)D levels were severely deficient in 3 individuals (7.5\%) and deficient in 30 individuals (75\%). In the ASSTpositive patients, 25(OH)D levels were severely deficient in 8 patients and deficient in 20 patients. In the ASST-negative group, 25(OH)D levels were severely deficient in 11 patients and deficient in 19 patients. There was no significant difference between the two groups. There was no significant difference in the mean of $25(\mathrm{OH})$ vitamin $D$ values between the ASST-positive, ASST-negative and control groups ( $p>0.05) .25(\mathrm{OH})$ $D$ levels, which were severely deficient in all patients with CSU, and its occurrence was significantly more frequent when compared with the control group ( $p=0.002$ ) (Figure 1). However, severely low levels were not associated with the disease severity.

Anti-TPO, anti-TG were detected in 15 of 60 patients (25\%) (ASSTpositive/ASST-negative: 8/7) and in 19 of 60 patients (31.6\%) (ASSTpositive/ASST-negative: $11 / 8$ ), respectively. Twenty-five of 60 patients 
Table 1. Comparision of gender and clinical findings in patients and control group

\begin{tabular}{|l|l|l|l|l|l|l|}
\hline \multicolumn{2}{|l|}{} & $\begin{array}{l}\text { Presence of } \\
\text { angioedema }\end{array}$ & Disease duration & UAS7 (mean \pm SD) & DLQI (mean \pm SD) \\
\hline Patient (60) & ASST + (30) ASST- (30) & $\begin{array}{l}22 \\
14\end{array}$ & $\begin{array}{l}2-300 \text { months } \\
2-180 \text { months }\end{array}$ & $\begin{array}{l}5.43 \pm 0.67 \\
4.67 \pm 1.29\end{array}$ & $14.47 \pm 6.47$ \\
\hline $\begin{array}{l}\text { Female: } 41 \\
\text { Male: } 19\end{array}$ & - & 0 & - & - \\
\hline $\begin{array}{l}\text { Control (40) } \\
\text { Female: } 26 \\
\text { Male: } 14\end{array}$ & 0 & 0 & & - \\
\hline
\end{tabular}

(41.6\%) were ascertained positive for at least one antibody. In the control group, anti-TPO and anti-TG were determined positive in $1(2.5 \%)$ and $4(10 \%)$ individuals, respectively. Four (10\%) individuals were detected positive for at least one antibody (Figure 2). TA positivity was found to be significantly higher in the patients than the control group ( $p=0.001)$. When anti-TG and anti-TPO were compared separately, the positivity of both antibodies was detected more frequently in the patient group $(p=0.012, p=0.003$, respectively). Disease duration was longer, and UAS7 was higher in anti-TG and/or anti-TPO positive patients compared with TA-negative patients ( $p=0.012, p=0.028$, respectively). Significant ANA positivity was also present in the TA-positive patients ( $p=0.001)$.

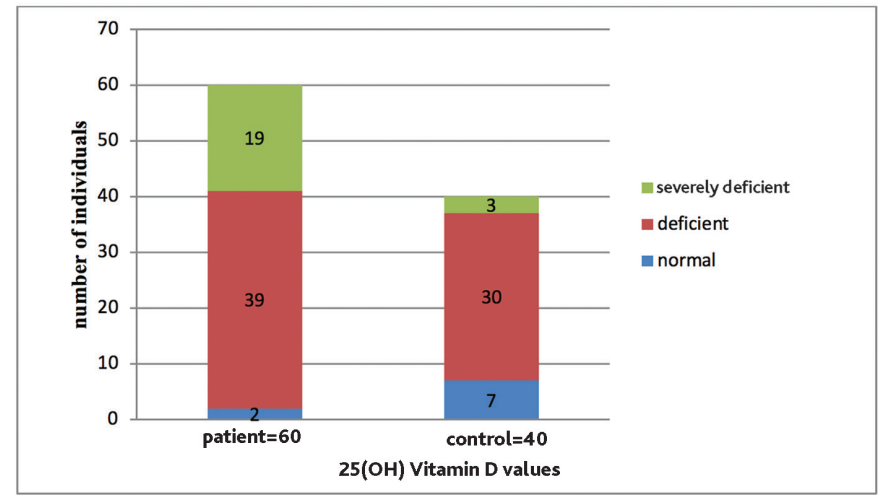

Figure 1. Comparison of 25 hydroxyvitamin $D$ values in patients and in control group. (Severely deficient: Vitamin $D<10 \mathrm{ng} / \mathrm{mL}$, deficient: Vitamin D 10-29 ng/mL, normal: Vitamin D $>30 \mathrm{ng} / \mathrm{mL}$ )

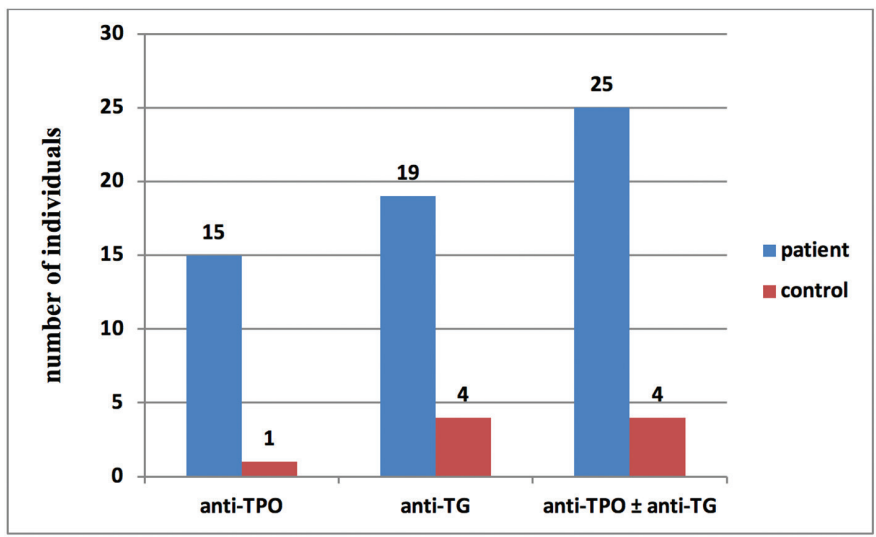

Figure 2. Comparison of anti-thyroid peroxidase (TPO), antithyroglobulin (Tg) and anti-TPO \pm anti-Tg positive patients and the control group
ANA was positive in 20 patients out of 60 patients (33.3\%) (ASSTpositive/ASST-negative: 11/9) and in 2 (5\%) individuals of the control group (Figure 3). ANA positivity was found to be more frequent in patients than the control group $(p=0.001)$. UAS7 and TA were significantly higher in positive ANA ( $p=0.042, p=0.000$, respectively). ANA-positive patients were examined for collagen tissue diseases. Notably, no patients were found to have any collagen tissue diseases. Basophil counts were $<0.1 \mathrm{k} / \mu \mathrm{L}$ in 22 patients (36.6\%) (ASST-positive/ ASST-negative: 11/11) and in $3(7.5 \%)$ individuals from the control group (Figure 4). A low-level basophil was detected in patients $(p=0.001)$. Interestingly, a significant negative correlation was found between the DLQI and basophil counts ( $p=0.039)$.

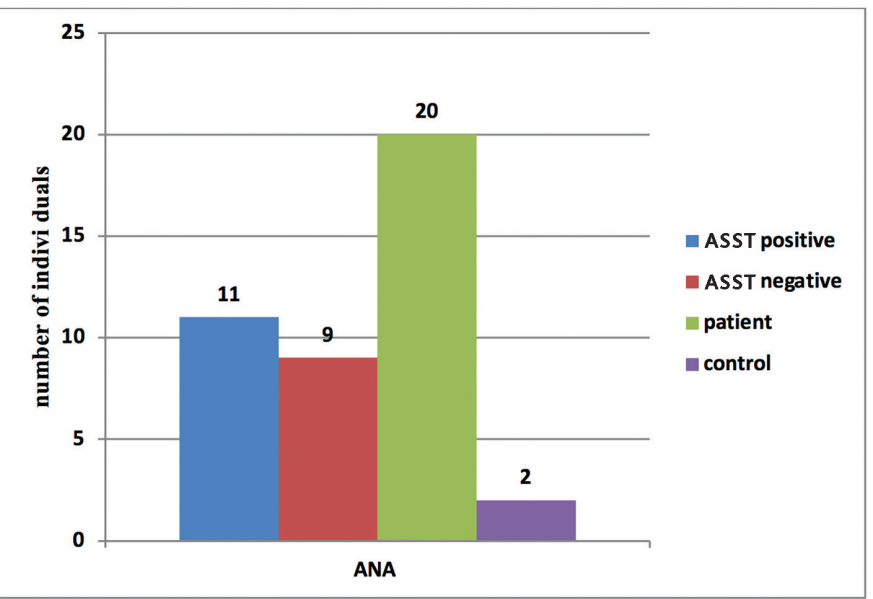

Figure 3. Comparison of anti-nuclear antibody positive patients and control group autologous serum skin test ANA: Anti-nuclear antibody

\section{Discussion}

Although the etiology of approximately $80 \%$ of CU is unknown, autoimmune mechanisms are thought to be involved in about $40-50 \%$ of CSU. Functional antibodies can be demonstrated indirectly by an in vivo method, $\mathrm{ASST}^{8}$. In two studies conducted by Vikramkumar et al. ${ }^{8}$ and Sahiner et al. ${ }^{9}$, ASST was found positive in 20 out of 48 patients with CSU (41.6\%) and in 21 of 45 children with CSU $(46.7 \%)$, respectively ${ }^{7}$. In our study, ASST was found positive in $50 \%$ of all patients, incongruent with the current literature. Generally, the disease symptoms are more severe in patients with ASST-positive compared with ASST-negative ${ }^{9,10}$. UAS7 is used for the evaluation of disease 


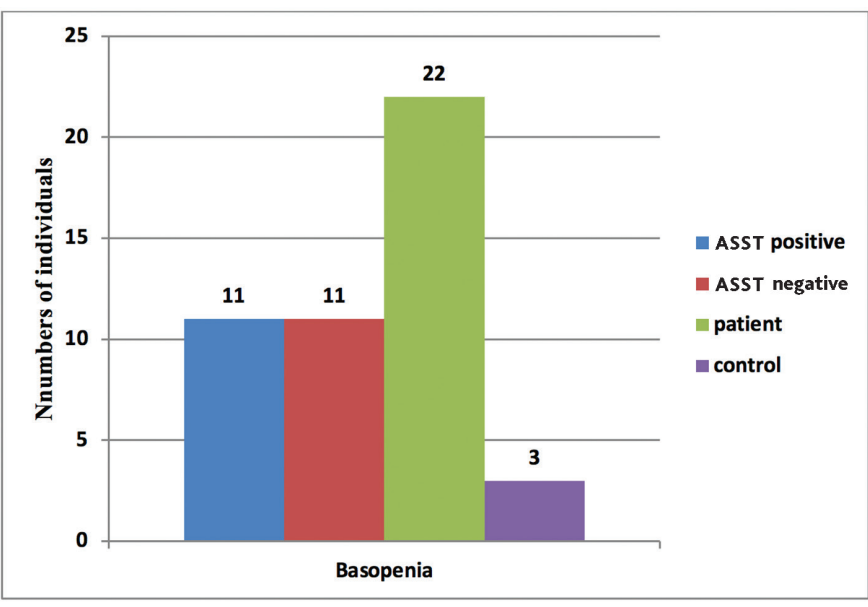

Figure 4. Comparison basopenia frequency in patients and control group autologous serum skin test

activity in $\mathrm{CSU}^{11}$. The severity of the disease can also be determined by accompanied angioedema and DLQI. In a study conducted by Magen et al. ${ }^{5}$, UAS7 was found to be significantly higher in ASST-positive patients $(p=0.041)^{6}$. In our study, the presence of angioedema, the mean of UAS7 and DLQI were found significantly higher in the ASSTpositive group ( $p=0.018, p=0.035, p=0.011$, respectively).

Recently, it has been proposed that vitamin $D$ deficiency may be related to many autoimmune diseases. $1,25(\mathrm{OH}) \mathrm{D}$ suppresses autoimmune diseases by suppressing the Th1 phenotype and strengthening the Th2 phenotype. Studies show that Th1 and Th17 cells play an essential role in the pathogenesis of CSU. Although many experts consider $\geq 30 \mathrm{ng} /$ $\mathrm{mL}$ as accepted doses for bone development and mineral hemostasis, the normal level of vitamin $D$ needed for the metabolism of the immune system is still unknown ${ }^{11,12}$. In our study, $<10 \mathrm{ng} / \mathrm{mL}$ levels were observed more frequently in patients than in the control group $(p=0.002)$. However, no correlation between urticaria severity and low vitamin $D$ levels was observed. There was no difference in vitamin D level between the ASST-positive and negative groups. Grzanka et al. ${ }^{13}$ found $<20 \mathrm{ng} / \mathrm{mL}$ levels were significantly more frequent in the CSU than in the control group. In a study performed by Chandrashekar et al. ${ }^{14}, 25(\mathrm{OH}) \mathrm{D}$ levels were found significantly lower in the ASST-positive group than ASST-negative in 45 patients with CSU. An important negative correlation between vitamin D and UAS7 was also detected. Abdel-Rehim et al. ${ }^{15}$ reported vitamin D levels were significantly lower in the patients, but no significant correlation was observed between vitamin D levels and disease severity. Other studies show that the prevalence of vitamin D deficiency was significantly higher, and the disease is more severe in patients with urticaria than in the control group ${ }^{16-18}$. These studies have reported that vitamin $D$ deficiency is related to CU. However, dissecting the relationship between CSU and vitamin $D$ deficiency is quite difficult due to the pandemic increase of vitamin D deficiency in the whole world. In a study conducted in Ankara by Uçar et al. ${ }^{19}$, quite a high proportion (51.8\%) of vitamin D deficiency was ascertained.

The studies also show that TA is more common in patients with CSU. Anti-TPO develops against TPO, a microsomal enzyme, and anti-TG is an autoantibody against $\mathrm{Tg}^{20}$. Thyroid autoimmunity increased in patients with autoimmune urticaria was first described by Leznoff et al. ${ }^{21}$.
Gangemi et al. ${ }^{22}$ reported that TA was positive in $32.6 \%$ of patients with CSU ( $n=95)$. In a study performed by Okba et al. ${ }^{23}$, TA was highly statistically significant in patients with ASST-positive when compared with patients with ASST-negative and healthy controls. Viswanathan et al. ${ }^{4}$ reported anti-TG and anti-TPO were positive in $6 \%$ and $26 \%$ of patients with CSU $(n=118)$, respectively. Consistent with these studies, we found that TA positivity was significantly higher in the patients than the healthy controls $(p=0.001)$. When anti-TG and anti-TPO were compared separately, the positivity of both antibodies was detected more frequently in the patients ( $p=0.012, p=0.003$, respectively). UAS7 was also found higher, and disease duration was significantly longer in patients with TA-positive than TA-negative. A study reported that the disease was more severe in patients with $\mathrm{TA}^{24}$. The pathogenesis behind the increase in TA in patients with CSU is still unclear. However the disease tends to be more severe and more prolonged in patients with CSU with TA positive ${ }^{24}$.

ANA is a non-specific autoantibody developing against an antigen in the cell nucleus. For years, it has been used for the screening of autoimmune diseases. ANA positivity is found more significant at the level of $\geq 1 / 160$ titration for autoimmune diseases. Lower titers may indicate normal immune activation ${ }^{4}$. In our study, ANA-positivity was found more frequently in patients than in the control group $(p=0.001)$. UAS7 and TA were significantly higher in patients who were ANApositive ( $p=0.042, p=0.000$, respectively). A study conducted by Viswanathan et al. ${ }^{4}$ reported $29 \%$ of patients with CSU were ANApositive $(n=131)$. Magen et al. ${ }^{5}$ detected in $14.6 \%$ patients with CSU were ANA-positive ( $n=171)$. The frequency of ANA positivity was found higher in the ASST-positive group than the ASST-negative and the control group. In addition, it was identified that the number of basophils was decreased, TA was higher, and the response to conventional therapies was less effective in the patients with ANA-positive ${ }^{5}$. ANA and TA are the most prevalent autoimmune disease-associated autoantibodies in $\mathrm{CSU}^{25}$. In our study, ANA positivity was found in $64 \%$ of at least 1 TA-positive 25 patients with CSU. Although the role of ANA-positivity in the pathogenesis of CSU is not known precisely, a strong positive correlation was found between ANA positivity and disease severity and resistance to conventional antihistamine treatment in $\mathrm{CSU}^{4}$.

Basopenia in peripheral blood has been detected in patients with CSU by many studies. Sabroe et al. ${ }^{26}$ had described that the number of basophil counts was nearly zero when this value was close to normal in patients with autoantibody-negative. In addition, an inversely proportional relationship was found between the number of basophils and the severity of CSU. In our study, the number of basophils was detected significantly lower in patients than in the control group ( $p=0.001)$, and a significant negative correlation was found between the DLQI and basophil counts $(p=0.039)$. A study by Magen et al. ${ }^{27}$ showed that the number of basophils was significantly lower in the ASST-positive group than the ASST-negative and the control group. Examining basophils in the blood may also form the basis for an autoantibody screening test.

\section{Study Limitations}

There are some limitations in our study due to seasonal variability of vitamin D and generally deficient levels in individuals in our country, and this complicates evaluating the relationship between inadequate vitamin D levels and CSU. 


\section{Conclusion}

CSU is a common disease that reduces the quality of life, and the etiopathogenesis of the disease is still unclear. Most cases of CSU can be controlled symptomatically by conventional therapy. However, the disease can be more severe in some patients and shows resistance to conventional therapeutic agents. Our study shows that low vitamin D levels, lower basophil count, and autoimmune markers such as TA and ANA have a significantly higher frequency of occurrences in patients with CSU. Our research indicates that the disease is more severe, impairs the quality of life, and the duration of the disease is longer in patients with positive autoimmune markers. Although the presence of autoimmune markers such as ASST, TA, ANA, and basopenia is essential to understand the pathogenesis of CSU better, the role of autoimmunity in the etiology of CSU should be identified by largescale studies. In addition, further investigation of autoimmune markers may identify the patients with severe CSU and may provide a novel therapeutic paradigm other than conventional treatment modalities.

\section{Ethics}

Ethics Committee Approval: The study was approved by the Ethics Committee of Sakarya University Clinical Research Ethics Committee, Turkey (approval number: 16214662).

Informed Consent: The participants signed and dated the informed consent document before participating in any study procedure.

Peer-review: Externally and internally peer-reviewed.

\section{Authorship Contributions}

Surgical and Medical Practices: M.T.E., N.M., Concept: M.T.E., N.M., Design: N.M., Data Collection or Processing: N.M., Analysis or Interpretation: M.T.E., N.M., Literature Search: N.M., Writing: N.M.

Conflict of Interest: No conflict of interest was declared by the authors.

Financial Disclosure: Sakarya University Scientific Research Projects Unit.

\section{References}

1. Zuberbier $T$, Aberer $W$, Asero $R$, et al: The EAACI/GA2LEN/EDF/WAO guideline for the definition, classification, diagnosis and management of urticaria. Allergy 2018;73:1393-414.

2. Movahedi M, Tavakol M, Hirbod-Mobarakeh A, et al: Vitamin D deficiency in chronic idiopathic urticaria. Iran J Allergy Asthma Immunol 2015;14:222-7.

3. Boonpiyathad T, Pradulopongsa P, Sangasapavirya A: Vitamin D supplements improve urticaria symptoms and quality of life in chronic spontaneous urticaria patients: A prospective case-control study. Dermatoendocrinol 2014;6:e1-7.

4. Viswanathan RK, Biagtan MJ, and Mathur SK: The role of autoimmune testing in chronic idiopathic urticaria. Ann Allergy Asthma Immunol 2012;108:337-41.

5. Magen E, Waitman DA, Dickstein Y, Davidovich $V$, Kahan NR: Clinicallaboratory characteristics of ANA-positive chronic idiopathic urticaria. Allergy Asthma Proc 2015:36:138-44.

6. Ferrer M: Immunological events in chronic spontaneous urticaria. Clin Transl Allergy 2015;5:30
7. Ito Y, Satoh T, Takayama K, Miyagishi C, Walls AF, Yokozeki H: Basophil recruitment and activation in inflammatory skin diseases. Allergy 2011:66:1107-13.

8. Vikramkumar AG, Kuruvila S, Ganguly S: Autologous serum skin test as an indicator of chronic autoimmune urticaria in a tertiary care hospital in South India. Indian Dermatol Online J 2014;5(Suppl 2):S87-91.

9. Sahiner UM, Civelek E, Tuncer A, et al: Chronic urticaria: etiology and natural course in children. Int Arch Allergy Immunol 2011;56:224-30.

10. Zuberbier T, Asero R, Bindslev-Jensen $C$, et al: EAACI/GA(2)LEN/EDF/WAO guideline: management of urticaria. Allergy 2009;64:1427-43.

11. Hossein-nezhad A, Holick MF: Vitamin D for health: a global perspective. Mayo Clin Proc 2013;88:720-55

12. Tuchinda P, Kulthanan K, Chularojanamontri L, Arunkajohnsak S, Sriussadaporn S: Relationship between vitamin D and chronic spontaneous urticaria: a systematic review. Clin Transl Allergy 2018;4:51.

13. Grzanka A, Machura E, Mazur B, et al: Relationship between vitamin D status and the inflammatory state in patients with chronic spontaneous urticaria. J Inflamm 2014;11:2.

14. Chandrashekar L, Rajappa M, Munisamy M, Ananthanarayanan PH, Thappa DM, Arumugam B: 25-Hydroxy vitamin D levels in chronic urticaria and its correlation with disease severity from a tertiary care centre in South India. Clin Chem Lab Med 2014;52:e115-8.

15. Abdel-Rehim AS, Sheha DS, Mohamed NA: Vitamin D level among Egyptian patients with chronic spontaneous urticaria and its relation to severity of the disease . Egypt J Immunol 2014;21:85-90.

16. Tsai TY, Huang YC: Vitamin D deficiency in patients with chronic and acute urticaria: A systematic review and meta-analysis. J Am Acad Dermatol 2018;79:573-5

17. Mohamed AA, Hussein MS, Salah EM, et al: Efficacy and safety of active vitamin D supplementation in chronic spontaneous urticaria patients. I Dermatolog Treat 2020;1-6.

18. Rather S, Keen A, Sajad P: Serum Levels of 25-hydroxyvitamin D in chronic urticaria and its association with disease activity: a case control study. Indian Dermatol Online J 2018;9:170-4.

19. Uçar F, Taşlıpınar MY, Soydaş AÖ, Özcan N: 25-OH Vitamin D levels in patients admitted to Ankara Etlik Ihtisas Training and Research Hospital. Eur Basic Med Sci 2012:2:12-5.

20. Monge C, Demarco P, Burman KD, Wartofsky L: Autoimmune thyroid disease and chronic urticaria. Clin Endocrinol 2007;67:473-5.

21. Leznoff A, Josse RG, Denburge J, Dolovich J: Association of chronic urticaria and angioedema with thyroid autoimmunity. Arch Dermatol 1983;119:63640.

22. Gangemi S, Saitta S, Lombardo G, Patafi M, Benvenga S: Serum thyroid autoantibodies in patients with idiopathic either acute or chronic urticaria. Endocrinol Invest 2009;32:107-10

23. Okba AM, Sheha DS, Moustafa AS, El-Sherbeny AA, Mohamed NA, Aglan MF: Association between thyroid autoimmunity and chronic urticaria in patients versus healthy controls. Egypt J Obes Diabetes Endocrinol 2015;2:84-9.

24. Chanprapaph K, lamsumang W, Wattanakrai P, Vachiramon V: Thyroid autoimmunity and autoimmunity in chronic spontaneous urticaria linked to disease severity, therapeutic response, and time to remission in patients with chronic spontaneous urticaria. Biomed Res Int 2018;2018: 9856843.

25. Kolkhir P, Borzova E, Grattan C, Asero R, Pogorelov D, Maurer M: Autoimmune comorbidity in chronic spontaneous urticaria: A systematic review. Autoimmun Rev 2017;16:1196-208.

26. Sabroe RA, Francis DM, Barr RM, Black AK, Greaves MW: Anti-Fc(episilon) $\mathrm{RI}$ auto antibodies and basophil histamine releasability in chronic idiopathic urticaria. J Allergy Cin Immunol 1998;102:651-8.

27. Magen E, Zueva E, Mishal J, Schlesinger M: The clinical and laboratory characteristics of acute spontaneous urticaria and its progression to chronic spontaneous urticaria. Allergy Asthma Proc 2016;37:394-9. 